\title{
Positive Politeness Strategies Used by Characters in an Animation Movie Script Entitled “Finding Dory”
}

\author{
Gede Darma Putra $^{1 *}$, I Gusti Ngurah Parthama ${ }^{2}$, Putu Lirishati Soethama ${ }^{3}$ \\ ${ }^{[123]}$ English Department Faculty of Arts - Udayana University \\ ${ }^{1}$ [email: dharmajerk@gmail.com] ${ }^{2}$ [email: parthama@fs.unud.ac.id] \\ ${ }^{3}$ [email:lirishatinya@yahoo.com] \\ *Corresponding Author
}

\begin{abstract}
The title of this study is Positive Politeness Strategies Used by Characters in an Animation Movie entitled "Finding Dory". This study is aimed at finding out the types of positive politeness strategies used to extend and respond by the characters to express the utterance in movie script and also what factors that influence the usage of positive politeness strategies in the "Finding Dory" movie. The analysis of this study is concerned with the utterance of positive politeness strategies of the characters. The data of this study were collected through conducting direct observation of the movie script "Finding Dory" produced by Pixar Animation Studios and directed by Andrew Stanton (2016). The collected data then were identified, classified, and analyzed qualitatively. The data derived from the script of the "Finding Dory" movie were collected and then, analyzed the polite expressions of characters used while doing conversation. After that, the selected data were analyzed based on the theory of politeness proposed by Brown and Levinson. Based on the result of the analysis, it was found that when extending and responding the utterance that contains positive politeness strategies, the characters used intensify interest to $\mathrm{H}$ (3), in-group identity markers (4), presuppose/raise/assert common ground (7), assert or presuppose S's knowledge of and concern for H's wants (9), offer, promise (10), be optimistic (11), including both $\mathrm{S}$ and $\mathrm{H}$ in the activity (12), give (or ask for) reasons (sub-strategy 13), assume or assert reciprocity (14). The most prominent factor that influences the characters to extend and respond the positive politeness strategies is the circumstances: sociological variables.
\end{abstract}

Keywords: Politeness Strategies, Positive Politeness, Face Threatening Acts

\begin{abstract}
Abstrak
Judul penelitian ini adalah Strategi Kesantunan Positif Digunakan oleh Tokoh dalam Film Animasi berjudul "Finding Dory”. Penelitian ini bertujuan untuk mengetahui jenis strategi kesantunan positif yang digunakan oleh tokoh untuk memperluas dan merespon dalam mengekspresikan ucapan berdasarkan naskah film dan juga faktor-faktor apa yang mempengaruhi penggunaan berkaitan dengan ujaran strategi kesantunan positif dari para tokoh. Data dalam penelitian ini didapatkan melalui pengamatan langsung terhadap naskah film "Finding Dory" yang diproduksi oleh Pixar Animation Studios dan disutradarai oleh Andrew Stanton (2016). Data yang terkumpul kemudian diidentifikasi, diklasifikasikan, dan dianalisis secara kualitatif. Data yang berasal dari naskah film "Finding Dory" dikumpulkan dan dianalisis ekspresi santun yang
\end{abstract}


digunakan oleh karakter saat melakukan percakapan. Setelah itu, data yang dipilih dianalisis berdasarkan teori kesantunan oleh Brown dan Levinson (1987). Berdasarkan hasil analisis, ditemukan bahwa ketika memperluas dan menanggapi ucapan yang mengandung strategi kesantunan positif, tokoh - tokoh menggunakan ; meningkatkan ketertarikan terhadap lawan tutur (3), menggunakan penanda yang menunjukkan jati diri atau kelompok (4), mempresuposisikan sejumlah persamaan penutur dan lawan tutur (7), mempresuposisikan bahwa penutur dan lawan tutur adalah kooperator (9), penawaran, janji (10), optimis (11), melibatkan lawan tutur dan penutur dalam suatu kegiatan (12), memberikan (atau meminta) alasan (13), mengharap atau menuntut timbal balik (14). Faktor yang paling menonjol yang mempengaruhi karakter untuk memperluas dan menanggapi strategi kesopanan positif adalah keadaan: variabel sosiologis.

\section{Kata kunci: Strategi Kesantunan, Kesantunan Positif, Face Threatening Acts}

\section{Background of the Study}

In communication, people have to consider the politeness principle, which is a set or systems in conversation when speaking. The principle is to consider the feeling of the hearer. In this case politeness is needed to reduce the factors of conflict or Face Threat. Polite utterances are often used in asking (requesting), offering, complaining, apologizing, because those request tend to threat to others.

A speaker must show awareness of the hearer's face and self-image through various strategies. To be successful in interaction with others, one has to follow some important strategies to be polite. People usually expect to be respected in social interactions. On this basis, there are four main strategies for performing Face Threatening Acts (FTA) as follows: Bald on Record, Positive Politeness, Off Record, and Negative Politeness.

This study discusses Positive Politeness from an animation movie script entitled "Finding Dory" by Andrew Stanton as a source of data because the movie set numerous records, including the biggest animated opening of all time in North America and has become the biggest Pixar film in China. The dialogue of the movie script was analyzed in order to get positive politeness strategies and ways of characters delivering the politeness strategies in the movie script.

\section{Problems of the Study}

The problem addressed in this study can be formulated as follows:

1. What types of positive politeness strategies are used to extend and respond the utterance by the characters in the movie script entitled "Finding Dory"?

2. What are the factors that influence the use of positive politeness strategies in the "Finding Dory" movie?

\section{Aims of the Study}

1. To find out the types of positive politeness strategies used to extend and respond by the characters to express the utterance in movie entitled "Finding Dory".

2. To analyze the factor that influences the positive politeness strategies in the "Finding Dory" movie.

\section{Research Method}

This study is completing all of the research methods that are needed.

\subsection{Data Source}


The source of data in this study is the animation movie from America, "Finding Dory", directed by Andrew Stanton. Finding Dory is a 2016 American 3D computer-animated comedy adventure film produced by Pixar Animation Studios. This study chooses the "Finding Dory" movie script because it represents positive politeness strategies in daily conversation.

\subsection{Method and Technique of Collecting Data}

The data of this study were collected through conducting direct observation of the movie "Finding Dory". The process of collecting data was done through searching and watching the movie from DVD, reading the movie script, comparing to the types conversation, and taking notes on the utterances.

\subsection{Method and Technique of Analyzing Data}

The collected data in this study are analyzed qualitatively using some linguistic theories. The collected data then were identified, classified, and analyzed qualitatively. Selected data were analyzed based on the theory of politeness proposed by Brown and Levinson (1987).

\subsection{Method and Technique of Presenting the Result of Data Analysis}

In this study, descriptive qualitative method was used in presenting data analysis of the movie script entitled "Finding Dory". The results of the data analysis were presented based on problems and selected the movie scene conversation based on the Brown and Levinson (1987).

\section{Results and Discussion 5.1 Synopsis}

Dory is a wide-eyed, blue tang fish who suffers from memory loss every some seconds or so. One day, she can remember is that she somehow became separated from her parents as a child. With help from her friends Nemo and Marlin, Dory embarks on an epic adventure to find them. Her journey brings her to the Marine Life Institute, a conservatory that houses diverse ocean species.

\subsection{Analysis of Positive Politeness Strategies in a Movie Script Entitled "Finding Dory"}

In this section, there are several types discussed and explained through the essence analysis of positive politeness strategies in the movie script entitled "Finding Dory".

\subsubsection{Analysis of strategy 3: Intensify interest to $H$}

Charlie: Dory, Dory, Dory! Kelp cake! Undertow, sweetie.

Jenny : Remember, honey. We have to stay away from the undertow.

The utterance is a directive speech (order) which indicates that the speaker $(\mathrm{S})$ is telling the hearer $(\mathrm{H})$ to pay attention and stay away from the undertow. Based on the speech, the words 'remember' and 'always' function to cause involvement for the $\mathrm{H}$ to pay attention to the speaker's speech.

\subsubsection{Analysis of strategy 4: Use in- group identity markers}

Young Dory : Okay, daddy. Charlie : No, no. Not daddy, I'm the nice fish that wants to be your friend, okay?

The usage of group identity 'daddy' in the speech confirms that speakers $(\mathrm{S})$ and hearers $(\mathrm{H})$ have a balanced position and close relationship using group identity markers. Brown and Levinson (1987: 112) proposed that this 
strategy includes in-group usage of address forms of language or dialect.

\subsubsection{Analysis of strategy Presuppose/raise/assert common ground}

Jenny : Dory, what happens if...You know, if you're gone for too long. And what if you get confused and that makes you distracted. And what if...

Dory : Mom. Mom. I lose you again?

The directive conversation (request) indicates that the speaker is engaged in a strategy by generating a perception ('what happens if / what if ...', ) of her speech to bring the other person more involved in the interaction created by the speaker.

\subsubsection{Analysis of strategy 9: Assert or presuppose S's knowledge of and concern for H's wants}

Jenny: You know, I like this Marlin already.

Dory :Yeah. And then somehow we found Nemo. Or did he find me? I don't know. But, you know what, Nemo is the sweetest. He just never gives up on me no matter what. What would Dory do?

In a directive conversation (advise), it states that speaker and hearer are cooperators. The speaker (Dory) affirms and implies the knowledge of the hearer's desire as a shared desire. Dory (speaker) convinces her parents by telling how she and Marlin struggle to find Nemo in a long adventure.

\footnotetext{
5.2.5 Analysis of strategy 10: offer, promise

Jenny : You found us.

Charlie: I'm never letting you go again.
}

Jenny : Oh my missing girl, you're here.

The directive dialogue (tell) above shows that the speaker makes a promise. Through a statement to the hearer by saying 'I'm never letting you go again', the speaker tries to give positive confidence and face to the statement given to the hearer in order to redress the potential threat of positive face threatening acts.

\subsubsection{Analysis of strategy 11: Be optimistic}

Fluke : Oh boy, this is gonna be good! What the... Gerald! Have you lost your marbles?

Rudder : Don't get used to it, Gerald!

The directive speech shows a sense of optimism. Fluke is very optimistic that they can escape together if they stop the truck by saying 'Oh boy, this is gonna be good!'.

\subsubsection{Analysis of Sub-strategy 12: Include both $S$ and $H$ in the activity \\ Dory : Let's go, we are stopping that truck. \\ Fluke : This I've got to see. \\ Rudder : Yeah, yeah, me too! \\ The speaker involves participants} by using the pronoun ' $w e$ '. By using ' $w e$ ' as an inclusive pronoun, the participants will feel involved in the activity suggested by the speaker (Dory).This strategy is done to save the face of the opponent.

\subsubsection{Analysis of strategy 13: Give (or ask for) reasons \\ Jenny : That's right. You found us. \\ Charlie : Honey, why do you think we stayed put here all these years?}


Because we believed one day you'd find us again.

Jenny : Exactly!

In the utterance above, the speaker (Charlie) asks Dory and immediately gives reason to the hearer (Dory).By asking and giving these reasons, the speaker is being optimistic that the hearer can do it as a good cooperator by utilizing one of the activities that may be remembered and performed.

\subsubsection{Analysis of strategy 14: Assume or assert reciprocity}

$\begin{array}{ll}\text { Bailey } & \text { : Trust me, I won't } \\ & \text { let you hit anything. } \\ & \text { Wall! } \\ \text { Destiny } & \text { : What's the point? I'll } \\ & \text { never learn to get } \\ \text { around! } & \\ \text { Bailey } & \text { : You better! If you } \\ & \text { can't do it in here } \\ & \text { you'll never do it out } \\ & \text { in the ocean. Now } \\ & \text { really focus, okay? } \\ & \text { Wall! }\end{array}$

The speaker expects and needs help from the hearers by doing FTA through command. By submitting to the instruction, the hearers will perform an action of the speaker's desire and is followed by the 'effect' statement if the hearer fails to perform the action.

\subsection{Factors Influencing of Positive Politeness}

There are some factors that influence speakers to use positive politeness strategy in order to criticize the hearer's behavior.

\subsubsection{The Payoff: a priory consideration. \\ Through on record plus} redressive payoff with positive politeness, the speaker can have opportunity to give face and to satisfy H's positive face. There are some respects of the speakers that make attentions to the hearers.

Charlie : Dory, Dory, Dory! Kelp cake! Undertow, sweetie.

Jenny : Remember, honey. We have to stay away from the undertow.

The speech 'Remember, honey.' can also be a tool to reduce the threat of positive face to the $\mathrm{H}$. This strategy is used by the speaker because the speaker wants to satisfy the positive face of $\mathrm{H}$.

\subsubsection{Relative Power (P)}

The next factor is that the speaker has a relative power $(\mathbf{P})$ to the hearer, which means that they have knowledge about the current situation that is happening among the conversations of the "Finding Dory" movie script.

Marlin: I heard. It's bringing back some very bad memories so let's get out of here. I say we go this way. Follow me. It's time to head home!

Dory : Wait, wait, wait! My parents are here.

The speaker knows the truth about the things they are arguing about. The speaker wants all of his instructions to be carried out, and resulting in a good cooperation.

\subsubsection{Social Distance (D)}

There is one factor which influences $\mathrm{S}$ to choose positive politeness strategy to deliver criticism to $\mathrm{H}$. The factor is the social distance (D) between the two participants in conversation.

$$
\begin{aligned}
& \text { Jenny : Remember, honey. We } \\
& \text { have to stay away from } \\
& \text { the undertow. }
\end{aligned}
$$


learned? "We see the undertow; and we say..."

The utterance 'honey', 'daddy' and 'sweetheart', it can be shown that the speaker expresses the speech of address form because it is wanted to show the family relationship between them. In addition to show the identity of the group, this strategy is done by speakers because the speaker wants to reduce the threat to the positive face of the hearer.

\section{Conclusion}

In the positive politeness strategies, S used some strategies: intensify interest to $H(3)$, use in-group identity markers presuppose/raise/assert common ground (7), assert or presuppose S's knowledge of and concern for H's wants (9), offer, promise (10), be optimistic (11), include both $\mathrm{S}$ and $\mathrm{H}$ in the activity (12),give (or ask for) reasons (13), and assume or assert reciprocity (14).

The factors influencing of positive politeness in "Finding Dory" movie script are: the payoffs, the social distance of speaker and hearer, and the relative power of speaker and hearer.

\section{Bibliography}

Brown, Penelope; and Levinson, Stephen. (1987). Politeness: Some Universal in Language. Cambridge: Cambridge University Press.

Creswell, J. (2003). Research Design: Qualitative, Quantitative and Mixed Methods Approaches (2nd Edition). California: SAGE.

Hornby, A.S. (2005). Oxford Advance Learner's Dictionary; $7^{\text {th }}$ Edition. London: Oxford University Press.

Leech, Geoffrey. (1983). Politeness Maxims[Internet]. Available from: wikipedia.org/wiki/politeness_ma xims-23k. [Accessed $25^{\text {th }}$ April 2017] 